\title{
ETHNICITY, STEREOTYPES AND ETHNIC MOVEMENTS IN NEPAL
}

Prakash Upadhyay, Ph.D., Assoc. Prof. of Anthropology

Tribhuvan University, Prithvi Narayan Campus, Pokhara

prak-socio@hotmail.com

\begin{abstract}
Liberal political environment, globalization, urbanization and migration amid the hectic political process of constitution drafting trapped in the issue of federalism and inclusion made the issue of ethnicity more debatable in Nepal. New ethnic identities were forged, new associations set up, and new allegations made in social, political, geographical and economic sectors for the reorganization of the country. Ethnicity does not always shoot out from antique tradition or nationality, however is fashioned, socially/culturally constructed, adapted, recreated, or even manufactured in the modern society. For that reason, it is necessary to see ethnicity as process i.e. making of boundaries, fluidity of boundaries as well as the stiffening of boundaries, variations in categorization and identification among groups in different times and places. Hence, State reorganization on the basis of capricious ethnic and religious history and so on will lead to confusion, disintegration and mayhem. The bases of successful Indian federation are characterized by geographic diversities, regional, cultures, and linguistic features. The finest inclusive democratic federalism, one could anticipate for in Nepal is some form of decentralized federalism based on geographic, regional and economic factors, in which there is an acceptance of regional and cultural/linguistic differences and proper democratic representation of population. The relationship between ethnic politics and representative democracy presents a dilemma for scholars and policy makers, however ethnic organizations are not adversative to democracy and that democratization with commitment can proceed in diverse and unpredicted ways by integrating diverse ethnicities, class, cultural, societal, historical and geopolitical realities . However, that requires development of the feeling of leadership, self-confidence and capacity development on the part of ethnic and marginalized groups to lead all caste and ethnic groups and a change in the stereotypical thinking of dominant groups.
\end{abstract}

KEYWORDS: Exclusion, federalism, ethnogenesis, oligarchy, ethnicisation, antithetical

\section{INTRODUCTION}

The ethno-linguistic composition of the population of South Asia is appallingly diverse. The majority of the population falls within four large linguistic family groups, Indo-Aryan, Tibeto-Burman, Austro-Asiatic and Dravidian. These groups are further subdivided into numerous sub-groups, castes and tribes however Indo-Aryans form the largest ethno-linguistic group not only in Nepal but also in North India, Bangladesh, Pakistan, Sri Lanka and the Maldives. In Nepal, the size of various ethnic/caste groups in the total population was hardly known before 1990 despite Nepal being a multiethnic, multilingual and multicultural country. The eleventh census of 2011, for the first time, identified more than 125 ethnic/ caste groups and more than 123 languages in multiethnic Nepal. A long history of the continuation of political autocracy, social exclusion, marginalization and exclusion from access to resources, services and opportunities, disempowerment, cultural and ritual debasement, discrimination and marginalization (on the basis of religious affiliation, caste, ethnicity, culture, language, territorial/geographical origin/remoteness and gender, and capacity 


\section{Crossing the Border: International Journal of Interdisciplinary Studies}

constraints) are the major impediments for the inclusion of diverse ethnic and caste groups in the national development efforts. Most of the achievements and resources through the past development process has gone to governing caste and ethnic groups, however, the issue of ethnicity in Nepal is exclusive and dissimilar from other countries. The diffident subordinate groups which came to be created slowly in Nepal were not due to colonialism or voluntary or involuntary migration (as in United States) or annexation but were created slowly by internal processes in the majority of cases.

Unlike in the United States of America, in Nepal, 'race' has never been perceived as a category no matter how strongly one has a tendency to find it. Except for those who came to Nepal during the last hundred years or so from the adjoining territories, Nepalese of all ethnicity may fairly be described as native people from different races like Mongoloid, Aryans, Dravidian etc. Race is connected to the cataloging of human bodies that are considered similar in certain ways. The creed of race evolved from the perception that there were innate biological differences between people of different skin colors and places, that- indeed- there were no ancestors common to all of humanity whereas ethnicity has to do with culture, a group of people with shared languages, meanings, foods, beliefs, religion, customs, traditions, etc. On the contrary, ethnicity is not just a person's race; it is about institutions, learned behavior and customs. It is about where anyone comes from, and celebrating the traditions and ideas that are part of that region. It has opportunity to change because groups can reject their own and embrace another in a process of assimilation. For example, Sanskritization process of Nepal and India before 1950, under which many ethnic groups was converted to Hindu life styles. Although there are numerous negative insinuations for the subordinate group status of numerous ethnic groups in Nepal, the consequences are not as severe as those faced by blacks in the United States of America, or Nazi Germany's Jews before 1945. In Nepal, the subordinate groups were never compelled by the dominant groups to leave the habitat or evacuate the country. This tendency of domination lacks evidences of heinous racial crimes as committed in the United States of America during the nineteenth century and even up to the mid 20th century.

Contrary to ethnicity, the word 'Indigenous' is a term quite different. Indigenous peoples are the original stewards of the environment or the Bhumiputra (son of the land), holding the land of their ancestors in trust for future generations. They have no history of migration from other places. They are those distinct and vulnerable tribes who possess only a limited ability to participate in, and are most often marginalized by the development process. They previously may have (or not) have long-term experience of self-governance. The original meaning of the term 'indigenous' is inborn that originates from a locality, those who uphold a combined identity through association with specific territories. Tribal, indigenous, ethnic minority, hunter/gatherer, etc. are used as analogous appellations, but meanings vary considerably depending on who sets the boundaries. A growing conflict exists between the supporters of the newly-emerging UN criteria for indigenousness and the over and over again unrealistic requirements demanded by certain non-native elites, particularly in Africa and Asia. In Nepal, there is flawed understanding on the definition of Indigenous groups. If hunting and gathering is the criteria for being called an indigenous group, are Raute the indigenous group of Nepal? Nepalese history reveals that about all the groups living in Nepal are the migrants from North, South, East or West. It signifies that the identification of indigenous peoples is hazy in Nepal.

There are ethnic groups with their distinct cultural traditions and beliefs and the legacy of subordination has created a sadistic situation in Nepal owing to which among the 


\section{ETHNICITY, STEREOTYPES \& ETHNIC MOVEMENTS}

excluded subordinated ethnic and caste groups (Dalits), there is comparatively high level of poverty and low level of development indicators - economic, education, health. They have comparatively very low access in productive resources, national policy and governance structures. Among multiple challenges, one of the challenges for them is to preserve their ethnic cultures, languages and traditions and progress ahead amid ethnic stereotypes in a volatile democracy. The ethnic stereotype prevailing in Nepali society is the crux which is a simplified and often misleading representation of ethnic groups history and origin, composed of what are thought to be typical characteristics of members of ethnic groups. In this article, I began by addressing the complex phenomenon of development of the notion of ethnicity and alterations, basic assumptions of ethnicity and ethnic identity, rise of ethnic sentiments and issues in Nepal, social exclusion and stereotype in education and finally end with ethnic movements and resolutions.

\section{DEVELOPMENT OF THE NOTION OF ETHNICITY AND ALTERATIONS}

Ethnicity and ethnic identity have become a major concurrent topic of debate. Ethnicity is a complex and sensitive issue. Sociological/ anthropological as well as historical knowledge appears to be critical in shaping the political debate on these issues. Ethnicity designates a group of people with separate identity and which is different from other groups. Ethnicity denotes ethnic we feeling of ethnic group members and can be said to exist when people claim a certain ethnic identity for themselves and are defined by others as having that identity (Barth 11). Identification with and feeling part of, and ethnic group and exclusion from certain other groups, are the features of ethnicity. Hence, words like 'We' or 'They' are used to make distinctions between ethnicity from other words, viz. ethnic identity. According to Symour-Smith, ethnicity may be objective or subjective, implicit or explicit, manifest or latent, or acceptable or unacceptable to a given grouping or category of people. As ethnicity is a multifaceted and susceptible issue, it is critical in shaping the political debate. The debate on ethnicity and ethnicity is not solely debatable at national level; rather it has become an issue of international debate. Joanna Pfaff-Czarneca at el. articulates, "Given the currency of ethnicity in international discourse, the mobilization of groups along linguistic, regional, or ethno-religious lines can no longer be analyzed merely in national contexts, nor are ethnic identities as we know them today self-evident categories" (41). Ethnic identity development comprises self-categorization in, and psychological connection toward, an ethnic group(s) and is portrayed as part of one's overarching notion. Ethnic identity development is depicted as a course of action of the construction of identity over time, due to a combination of experience and actions of the individual and includes gaining knowledge and understanding of in-group(s), as well as a prudence of belongingness to an ethnic group(s). Ethnic identity is occasionally interchanged with, held distinct from, or well thought-out as overlapping with racial identity. This incongruity in the distinction (or lack thereof) between these concepts may originate from the incongruity of definitions of race and ethnicity as well as the historic conceptualization of models and research surrounding ethnic and racial identity. Research on racial identity development emerged from the experiences of African Americans during the civil rights movement in the United States of America, however expanded over time to include the experiences of other racial groups. The notion of racial identity is over and over again misunderstood and can have numerous meanings which are derived from biological dimensions and social dimensions. Biologically, race is resultant from an individual's physical features, genetic material pools, and character qualities, etc. The social construction of racial identity can be referred as a sagacity 


\section{Crossing the Border: International Journal of Interdisciplinary Studies}

of group or collective identity based on one's perception that he or she shares a common legacy with a particular racial group, what an individual look like and how that individual is treated in the society that consequently furnish to ethnicity sentiments.

Ethnicity does not always shoot out from antique tradition, biology or nationality, however is fashioned, socially constructed, adapted, recreated, or even manufactured in the modern society. The speedy process of urbanization and the growth of multicultural cities amid the hectic political process of constitution drafting trapped in the issue of federalism have made the issue of ethnicity more germane in everyday discussions in Nepal in an ostensibly diverse ways. Gellner and Guneratne squabble that the socially constructed notion of ethnicity has very different meanings for state, society and individual and that the ethnicity at work is no longer same as it was before (21-34). Ethnicity ought to be studied in the historical sense. It is imperative not only because it is one of the interesting core areas of sociology and anthropology for examining human similarities and differences from physical and cultural point of view but also to address the present debates and issues on ethnicity although ethnicity is a new term conversed in recent times.

Sociologists believe that the term 'ethnicity' is a relatively recently coined term although the word 'ethnic' is derived from the Greek 'ethnos' (in turn derived from 'ethnikos'), originally meaning 'heathen' or 'pagan' i.e. an offensive term that deliberately insults somebody who does not acknowledge the belief of Christianity or in other words, the term 'ethnicity' was at first used to substantiate the difference among the Christians and non-Christians in the world. It was used in this sense from the mid fourteenth century until the mid nineteenth century, and then it gradually began to develop 'racial' connotations (to be linked with lineage and kin solidarity). Eriksen cites Glazer and Moynihan as noting that the word's first appearance was in the Oxford English Dictionary of 1972 (57). Regmi quotes Glazer and Moynihan that the term ethnicity was for the first time used around 1953 (11). 'Ethnicity' and 'race' are not popularly regarded as mutually exclusive concepts as 'ethnicity' is deemed to be more polite and less controversial term for 'race' (Popeau 27). Since then, the concept of 'ethnicity' has been altering in terms of its meaning and usages but one thing common is that it has always been based on the dialectic interaction of both apparent similarities and divergences in terms of some indicators.

The term 'ethnicity' was coined, Scott and Marshall bicker, that in contradiction to race which is often seen in biological terms. Members of an ethnic group may be identifiable in terms of racial attributes, but they may also share cultural characteristics such as religion, occupation, language, or politics. Ethnic groups should also be distinguished from social classes since membership generally cross-cuts the socio-economic stratification within a society, encompassing individuals who share (or are perceived to share) common characteristics that supersede class. For example, the Jews in the United States of America constitute a typical ethnic group, since they include individuals of racial origins (from East Europe to North Africa), social classes, mother-tongues, political beliefs, and religious commitments) from orthodox to atheist), yet still consider themselves to contribute to a common Jewish identity that distinguishes them from, while not necessarily placing them in opposition that distinguishes them from, while not necessarily placing them in opposition to, a wider American society.

E.B. Taylor's Dictionary of Anthropology claims that the ethnic refers to a group distinguished by common cultural characteristics, e.g. a linguistic group like the Bantu or Malayo-Polynesian (191). Sociological definition of ethnicity is also similar. John Scott and Gordon Marshall edited Dictionary of Sociology delineate that individuals who consider themselves, or are considered by others, to share common characteristics that differentiate 


\section{ETHNICITY, STEREOTYPES \& ETHNIC MOVEMENTS}

them from the other collectivities in a society, and from which they develop their distinctive cultural behavior, form an ethnic group (226-27). Ethnic groups are fluid in composition and subject to changes in definition. New ethnic groups are constantly being formed as populations move between countries. Pakistanis, Nepalese, Indians, Caribbean people in Britain, for example, constitute an ethnic group although as individuals in their countries they would be seen to be members of quite different groups in terms of ethnic/caste and languages they speak. The concept of ethnicity is particularly important when it forms the basis for social discriminations (as for example, in the case of Jews in Nazi Germany) or for independence movements as in the former Soviet republic states. Ethnocentrism is the term closely embedded with ethnicity. It is sometimes portrayed as a kind of stereotype, a serious peccadillo since this is the practice of studying and making judgments about other societies in terms of one's own cultural assumptions or preconceived notion of ethnic identity.

By the 1960s the notion of the ethnic was beginning to be replaced by the, perhaps less embarrassingly colonial, 'ethnic group.' The incident that most evidently manifested an anthropological paradigm shift, from the study of 'tribal society' to the social constructionist model of 'ethnic groups' which is existing at present, was the publication of Fredrick Barth's Ethnic Groups and Boundaries. In this book, Barth identified four theoretical features of the conventional, taken-for-granted model of the corporate, culturally distinct ethnic group; first, such a group was biologically self-perpetuating; second, members of the group shared basic cultural values, manifest in overt cultural forms; third, the group was a bounded social field of communication and interaction; and fourth, its members identified themselves, as were identified by others, as belonging to that group (4-13). He summarized the 'Basic Social Anthropological Model of Ethnicity' in terms of four major propositions, which are the following:

i) Ethnic identification always involves a dialectical interplay between similarity and difference;

ii) Ethnicity is centrally a matter of shared meanings i.e. the culture and that the culture is also produced and reproduced during interaction;

iii) Ethnicity is no more fixed or unchanging than the way of life of which it is an aspect or the situations in which it is produced and reproduced;

iv) Ethnicity, as identification, is collective and individual, externalized in social interaction and the categorization of others, and internalized in personal self-identification.

\section{CONJECTURES OF ETHNICITY AND ETHNIC IDENTITY}

a) Fundamental Conjectures of Ethnicity

1. The persistence and maintenance of ethnic boundaries must be analyzed and understood within appropriate social and cultural contexts (Barth 15).

2. Guneratne argues that ethnicity is the outcome of specific historical process that shapes a society's experience (26-28).

3. There must be a 'We-They' dichotomy to apply the concept of ethnicity.

4. Ethnicity can be explained with the help of different theories-primordialist, modernists or instrumentalist.

5. The study of ethnicity relates to cultural persistence and change including crossing of established boundaries and construction of new boundaries.

6. Ethnicity can be objective or subjective, implicit or explicit, manifest or latent, acceptable or unacceptable to a given grouping or category of people.

7. Ethnicity may subjective or objective, implicit or explicit, manifest or latent to a given category of people. 


\section{Crossing the Border: International Journal of Interdisciplinary Studies}

\section{b) Fundamental Conjectures of Ethnic Identity}

1. Identities must be understood in the specific territorial, social, cultural and political contexts.

2. Identities are formed and transformed as the circumstances in which individuals and societies find themselves change.

3. Ethnic Identity emerged in social psychology out of Social Identity Theory. Social identity theory posits that belonging to social groups (e.g. religious groups or occupational groups) serves an important basis for one's identity.

4. Collective identity must be understood and analyzed in the context of underlying structures of political, economic and social relations that generate them.

5. Self-conscious ethnic awareness and positive esteem forms the basis of ethnic identity.

6. Ethnic identity is embedded with identity development emphasizing the multidimensionality of group membership collective identity.

7. Ethnic identity development serves as a buffer between perceived discrimination and depression.

\section{THE RISE OF ETHNIC SENTIMENTS AND ISSUES IN NEPAL}

Until 1951, members of the autocratic feudalistic Rana oligarchy held complete control of the government in Nepal. In 1951, after a popular revolt led by the Political parties, the autocratic Rana oligarchy came to an end, but the residual of feudalism with political and dependency nexus endures even to the present. The 21 st century Nepali society is partly a semi-feudal society in which the landholding is the prime source of all social, economic and political powers. The caste ridden and priest ridden Nepali society depicts a highly asymmetrical society in which caste, ethnic, religion and political factors plays a vital role in determining the status of an individual and a group. The unequal allocation of natural resources including farming land in an agricultural country like Nepal demonstrates how undemocratic Nepal is in a real sense. This has given rise to social tensions, prejudiced development and discriminating paucity. Nepal's prototype of land ownership (a reminiscence of feudalism) is the consequence of over 240 years of autocratic monarchy and Rana regime, with successive Shah kings and oligarchic Rana rulers treating the land as their private property; allocating large tracts to the people close to them especially the government officials, priests, military leaders, and family members, in lieu of salaries or as gifts for their devotions. For the time being, this feudal system deliberately excluded common people from owning land (a symbol of power and prosperity) and ensured their continued position as excluded agricultural tenants. Dominant groups close to the ruling elites held large tracts of land and were influential, but those who were never close to ruling elites such as Dalits (socalled low caste Hindus) and many other ethnic groups became the excluded groups in the long run and they became dependent on the former forever. However, some other groups who tended to lose land due to debts or any other socio-economic or political reasons (official confiscation of land) had not sufficient to continue to subsist. Mainly the ethnic groups, Dalits, and in some cases, many Brahmins and Chhetri had to depart and look for occupation and land in Bhutan, Darjeeling, Sikkim, Assam and the northeast Indian States. This process continued for centuries but halted in 1990 when there occurred a political change with the restoration of multiparty democracy after a lapse of thirty years when it was legally banned by King Mahendra in 1960. The emerging trend of globalization in early nineties amid rising unemployment and political instability inspired many young people (from all caste and ethnicities) to seek jobs in gulf countries and south-east Asian countries instead of 


\section{ETHNICITY, STEREOTYPES \& ETHNIC MOVEMENTS}

looking for occupations in India and other neighboring countries where their ancestors had been going for the past many centuries for making a living.

The post-democratic period of 1990 proved to be capricious from all aspects. For the first time in its history, the issue of ethnicity-building was raised. New ethnic identities were forged, new associations set up, and new allegations made in social, political and economic sectors. The kind of national identity that was propagated in schools and through government organizations with autocratic legacy of the past was noticeable as highly exclusionary by ethnic groups, lower castes, by religious minorities, and by ethnic Madhesis (Tarai people) living in the economically decisive Tarai region in the south of the country. Madhesis alleged that the hill dwellers of Nepal have developed an ethnic stereotype towards the Madhesis which is a simplified and often misleading representation of an ethnic group, composed of what are thought to be typical characteristics of members of a given group. Other ethnic groups also assert that throughout their history they have been excluded from various rights, hence, they bicker; the issue of their exclusion should be linked with the issue of ethnicity. In the past, ethnicity and religion never became a prominent issue in the politics of Nepal. This was particularly the case during the party-less Panchayati era, during which a sturdy emphasis was put on the undesirability of religious and ethnic politics as part of the efforts to consolidate national identity and unity. After the people's revolution in 2006 and the consequent establishment of republican set-up in 2008, both forms of identity seemed to come increasingly to the forefront, and accusations of ethnic or religious bias are today commonly voiced in the political discourse of the country. Although this logic seems lucrative politically, but there are dangers of defining exclusion only in terms of caste and ethnicity. There are high chances of politicization of ethnicity charm.

In the case of tarai, before the emergence of the modern concept of nationhood and citizenship, Prithvi Narayan Shah, the founder of modern Nepal in the mid-eighteenth century, in the name of nationalism, had given high political and social-cultural priority to hill dwellers. For the Shah and Rana rulers', tarai was a mere satellite, a colony to extract revenue from land and natural resources. The Nepali nationalism, largely conceived and institutionalized, structured around the Hindu monarchy, Rana oligarchs, autocracy, Hindu religion and the Nepali language. These restrictive concepts have always excluded tarai people, whose distinct cultures and cross-border link with India have led hill Nepalese to view them with suspicion and derision. The psychological distance between tarai people and the Nepali state, as well as other citizens, has been historically motivated by discriminatory policies. Some of this distance is centuries old but much reflects the more deliberate constructs of Rana oligarchs and party-less Panchayati policies. The Panchayati slogan "ek desh, ek bhesh, ek bhasa" (one country, one dress, one language) proved perilous to tarai people and to many ethnic groups. The slogan one dress, one language tried to design a new united Nepali identity with a common dress Daura-Suruwal-Dhaka Topi (Nepali trouser and Nepali cap) and one language (Nepali language) excluding all others, but failed despicably to give equal caste/ethnic/religion/region based egalitarianism to all Nepali masses. The cumulative effect as a form of internal colonization of tarai proved precarious and demand liberation from domination. Owing to a justifiable grievance of the people of the tarai, because of political marginalization, failure to recognize their numbers and so on Madhesh is a lumpy category although other groups like the Tharus disassociated themselves from Madhesis. Fredrick Gaize in his book Regionalism and National Integration in Nepal had rightly argued that though discontent may be latent and dormant at present however may be grave and explosive stipulation may occur in future (76-81). This prediction of Gaize came true in 2007 


\section{Crossing the Border: International Journal of Interdisciplinary Studies}

when the tarai movement erupted thirty two years after the publication of Gaize's book. The low level of human development associated with pronounced spatial disparity and social exclusions - social, cultural, political, religious, educational, etc. is entirely a cultural and political construct, stereotyped by the attitudes of influential.

\section{SOCIAL EXCLUSION AND STEREOTYPE IN EDUCATION}

Social exclusion is prevalent in various forms - social, cultural, economic, educational, religious, etc. Primarily, through language and culture, the ruling elites excluded all others from the mainstream of development for centuries. This is what has been customarily continuing in South Asian Countries - mainly in Nepal. Bhattachan has alleged that discourse on social exclusion and inclusion in Nepal is the same to old wine in a new bottle (11). In a broad spectrum, social exclusion is a process by which certain groups are systematically disadvantaged because they are discriminated against on the basis of their ethnicity, race, religion, sexual orientation, caste, descent, gender, age, disability, HIV status, migrant status or where they live. Discrimination occurs in public institutions such as the legal system or education and health services as well as social institutions like the household and in the community (Beall \& Piron 8-10). While there is a considerable debate about the precise meaning of the term, some of the most useful definitions have sought to emphasize that social exclusion is concerned with the inability to participate effectively in economic, social, and cultural life and, in some characteristics, alienation and distance from mainstream society (Duffy 47 ).

In contrast to poverty and unemployment which focus on individuals or households, social exclusion is primarily concerned with the relationship between the individual and society, and the dynamics of that relationship. In fact, in many ways, it appears useful to emphasize similarities between the debates about social exclusion and the debates as no societies and groups in the world are entirely inclusive, yet the groups affected and the degree of discrimination varies from one society to another, as do the forms that social exclusion takes. Some forms of discriminations are manifest and deliberate, unofficial, or subtle and unintended. It is the vicious cycle of social exclusion that causes the poverty of particular people, leading to higher rates of poverty among affected groups. The productive capacity and poverty reduction rate is reduced by social exclusion. The development of a society as a whole is obstructed and the competent operation of market forces are thwarted which restrains the economic growth. Discrimination is such traumatic that in the labour market it may make parents decide not meaningful to invest in their children's education. Socially excluded groups often do participate but on unequal terms. Labour markets illustrate this most clearly by exploiting the powerlessness of excluded groups and at the same time reinforcing their disadvantaged position. It is the logic of social exclusion that enlighten why some groups of people remain backward and poorer than others, have less food, die younger, are less economically or politically involved, less educated and are less likely to benefit from services. It is the social exclusion that leads to conflict and insecurity. Excluded groups who are the victim endure from multiple disadvantages that may come together when they have multiple sufferings, unequal rights, denied rights, discriminated and feel marginalized from the mainstream society. Social excluded people can be an easy victim of discriminations and stereotypical behavior in education. One can see social exclusion among non-disabled groups as socially generated barriers that reduce the ability of the excluded to interact with society. Room adds a new dimension to the discussion on social exclusion by couching the issue of social exclusion in a rights-based language when he talks about social exclusion 


\section{ETHNICITY, STEREOTYPES \& ETHNIC MOVEMENTS}

as the denial or non-realisation of civil, political, and social rights of citizenship (74). Such a rights-based approach to the problem of social exclusion has much to recommend. It has great affinity with the capability approach developed by Amartya Sen which calls for efforts to ensure that people have equal access to basic capabilities such as the ability to be healthy, well-fed, housed, integrated into the community, participate in community and public life, and enjoy social bases of self-respect (Sen 7-21). The term social exclusion would be seen as the rejection of the latter three important capabilities. The right to education, for example, in a dignified manner reserves a special position, but there prevails different occurrence of discriminations.

For instance, do students from a certain ethnic groups and so-called low castes have to deal with ethnic stereotypes on a daily basis? While stereotyping in broad-spectrum reflects our expectations and beliefs about the group in question, ethnic stereotypes tend to be negative and prejudicial. Ethnicity may be accredited to, or understood by, individuals; ethnic awareness is not a mechanical subjective correlate of the objective ethnic category. It is notable that ethnic identity may be supposed by others within or outside the group, or forced by foreigners. People are assumed to be members of ethnic groups, not only in fashionable phraseology but also by anthropologists, sociologists and other academics, without careful consideration of the extent to which an ethnic category is actually a group. Fashionable discernment of ethnicity is consistently built upon images constructed up over time, possibly over generations. Many admired views have been inherited through intergenerational socialization processes. Hence, while an ethnic group could be defined impartially based on certain conventional criteria, it may more precisely symbolize a professed appearance group: a cumulative, category or group of people who are perceived as being distinguishable from a total population because of certain unique characteristics which have high social import for a particular social system. Trendy acumen on ethnicity and ethnic behavior frequently assume the form of stereotypes which is an exaggerated belief associated with some particular category, especially of an ethnic, national, racial or religious minority group. To a substantial degree, ethnic or racial group stereotypes replicate the conventional dealings of perceived appearance groups or racially excluded people.

Stereotypes are frequently cultured through socialization and armored through social interactions between members of different groups. Stereotypes may be discerned like usually derogatory epithet for ethnic groups, announcement concerning perceived appearance which may contain typically depressing emotive meaning, endow with a linguistic gauge of past and present relationships between the object-group and the name-callers. There may be ethnic jokes, which are told because the teller acknowledges the underlying basis or assumptions about the ethnic group or individuals who are the brunt of the hilarity. Most probably the listener also contributes to these assumptions or the humor would be mislaid. Fabricated stories and publications professing to be non-fiction have consistently denigrated selected ethnic minority groups, thereby put in motion the chauvinism of covert or noticeably unreceptive readers. In Nepal, stereotypes are at hand and affecting students because of the phenomenon of stereotype threat. For example, the popular stereotype prevailing in Nepali society is that Lahures (people serving in foreign military services) children are not serious in study, Brahmin and Chhetri students are born to be educated and hence are razor-sharp in study, Madhesi students are deviated but good in mathematics/science, or Dalit children are of low strata and hence cannot study, etc. Students will live up or down to perceived expectations of self prophecy. The realities of stereotypes embedded with social constructs about ethnicity cannot be ignored, which is lucid from the noteworthy gap between the 


\section{Crossing the Border: International Journal of Interdisciplinary Studies}

share of population of ethnic and Dalit in relation to their school going age population and enrollment in Nepal. This explains why a significant number of children of ethnic and Dalit children are outside the school system. The share of enrollment of indigenous peoples and Dalit is lower than their population size. The hill ethnic groups and Dalits are comparatively better in education than tarai ethnic groups and Dalits. Education of Tarai Dalits is very meager. Dalit girls' school dropout rate is lofty in all grades. Among multiple reasons, poverty and social discriminations embedded with stereotypes are the major ones.

Dalit settlements in both hills and tarai are usually isolated and generally schools and colleges are located far flung and renting the rooms without caste based discrimination, which is difficult. In many cases, teachers from higher castes preoccupied with stereotypes use and/or pass deprecating remarks or proverbs or examples against Dalits in the class. In many rural schools, Dalit students sit separately on back benches and also deprived from using educational materials and equipment. Their participation in sports and extra-curricular activities is very low. Other forms of discriminations are no greeting by non-Dalit students and disobedience to Dalit teachers by non-dalit students. Dalit students feel discriminated, depressed, frustrated and terminate schools. Most of Dalit children also give up school as their parents compel them to do household chore, take care of their younger siblings or do wage earning labour.

The issues related to the overrepresentation of some groups such as Brahmin-Chhetri and Newar and underrepresentation of others such as Dalits, ethnic groups, Madhesis and religious minorities in education, the state and polity is surfaced heatedly. It is now generally believed that without inclusion in education, it is impossible to accomplish inclusion in other sectors because the credentials provided by education are supposed to level the playing field and make it fair, just and universally acceptable. Once impartiality of opportunity in access and outcome is achieved and institutionalized in education, it may not be essential to have separate provisions for inclusion in the other sectors in societies that believe in and practice genuine meritocracy.

\section{ETHNIC MOVEMENTS IN NEPAL AND RESOLUTIONS}

The constitution of 1990 defined Nepal as a multi-ethnic, multilingual, democratic, independent, indivisible, sovereign, and Hindu country. Ethnic and religious activists were disenchanted that the influential word 'Hindu' was still there; none the less, the adding together of the words 'multi-party', 'multi-ethnic,' 'multilingual' and 'constitutional monarch' was a great feat during the early 1990's. But well before 1990, it was only in the late seventies and early eighties that the growing self-consciousness of ethnic elites led to the formation of ethnic organizations. As a turning point, one can identify the students' movement of 1979 and the national referendum of 1980 which led to constitutional changes undermining the partyless conservative basis of the monarch. The people saw that political and social changes were possible by mobilizing the masses. Because of Nepal's ethnic composition and diversities, the ethnic organizations only represented very small sections of society, even though their matters of concern were very genuine and similar in nature. So the organizations started informal talks which, in 1986, led to the formation of the Forum for the Rights of All Nationalities (Sarvajati Adhikar Manch). The ethnic leaders not only wanted a change of the political system but also socio-political modifications and economic participation at a broader range. However, it was only after the political change of 1990 that ushered in an exclusively new situation, and fired the starting gun, so to say, on a rapid and not entirely predictable process of ethnogenesis similar to what happened in India under the British Raj and for rather similar reasons (Whelpton 


\section{ETHNICITY, STEREOTYPES \& ETHNIC MOVEMENTS}

39-41). The surprising rise of identity politics after the restoration of democracy in 1990 led to increasing academic and political attention on political exclusion and ethnic politics, however, many aspects of exclusion yet to be analyzed, additional dimensions of exclusion and inequality requiring further calisthenics. The interactions between formal and informal institutions and political exclusion, inter-group inequality, ethnicisation of the business sector and the country's protracted democratization in addition entail further glance.

For the first time in the history of Nepal, such a condition emerged that the hegemony of high caste hill dweller Hindus was challenged with the publication, for the first time in 1991, of data on caste and ethnic group affiliation. Ethnicity does not always emerge from historic tradition or nationality, but is formed, socially/culturally constructed, adapted, recreated, or even manufactured or even misused in the modern society. In post $1990 \mathrm{Nepal}$, ethnic differences began to acquire increasing political salience. The census data revealed the population size of different ethnic groups and liberal political environment encouraged the different groups to organize openly for the first time. For the first time, Nepalese and their friends have had to learn a new word for 'tribe' since the beginning of the 1990s, namely, janajati ( a word fairly synonym to ethnic group).The term seems to have come into Nepali from Bengali, via Darjeeling (Gellner 18-25). He argues that it was completely unknown in the early 1980s, started to be used in activist circles shortly before 1990, and now has wide currency among the political elite, though it is still far from being universally recognized in the wider population. It picks out those groups previously known as 'hill tribes' (plus the Tharus and similar groups, e g, Santals, from the tarai). The distinction between caste and janajati thus corresponds more or less to the Indian distinction between caste and tribe - with the important proviso that in Nepal the janajatis comprise a much larger percentage of the population (the exact percentage is debated: some claim they are as much as 40 percent or more of the overall population although the census results varies).

Furthermore, since 1990, there has been a dramatic shift in the orientation toward ethnicity in terms of approaches used in different studies. Though, studies on prejudice are very few done in the context of Nepal, the history is evident of its metamorphosis in terms of approach and actual practices. Both conscious and obvious factors are responsible in such a transformation on the pattern of ethnicity and prejudice in Nepal. Gellner alleges that most of the studies in ethnicity in Nepal are not equipped with appropriate theories and models and the academic sophistication too is too low here as compared to west which is, among other things, due to the relatively new introduction of sociological and anthropological researches in Nepal (25). Despite of the substantive contribution in anthropology of Nepal from both domestic and foreign scholars, studies on ethnicity, its boundary is less common and when it comes to chauvinism in everyday life it is much less. Locating the existing cultural and ethnic groups is still under process even at the present when Nepal is struggling hard to find a new constitution that can introduce and incorporate the rights and sentiments of all ethnic and caste groups.

An ethnic federal state is the major demand of ethnic groups and also a major barrier in the path of drafting new federal constitution. However, Nepal does not have the historic circumstances on its side as in the Switzerland or USA where already functioning state entities with long history of separate political and administrative existence came forward to form a new federation. State restructuring has created a major challenge in creating federalism in Nepal. Nepal remained a unitary state since the time of unification of Nepal by Shah King Prithvi Narayan Shah in the late 18th Century. Currently, Nepal being on the path of a federal state means that Nepal will need to revive itself and restructure the state to 


\section{Crossing the Border: International Journal of Interdisciplinary Studies}

create federal units so that to delegate more powers to excluded groups. State restructuring often becomes a blistering controversial issue when a country is going federal on the basis of desegregation. But state restructuring on the basis of ethnic federation remains highly disputed and controversial and it continue to plague state restructuring debate and constitution drafting process. The demand of ethnic federation by some political and ethnic organizations has been rejected by major old parties. The Madhesi community's want of entire tarai belt to be declared as Madhes Pradesh has been opposed vehemently. If a federal state in Nepal is organized on ethnic basis, for example, may be Tamuwan or Limbuwan or Magarat or Khasan, the majority of the people in that area are not Tamus or Limbus or Magars or Khasa. Not only do there will be a quandary of minority dominating the majority, but there will be the problem of states which are defined by the ethnic identity of a minority. It will be illogical if we have a glance at the mosaic of different groups in Nepal. To make solely ethnic identity as a basis of political support may be a perilous and misleading philosophy. Hence, organization of the country on the basis of ethnic and religious groups and so on will lead to disintegration and anarchy. The politically premeditated approach drawing on the support of the ethnic, religious groups or caste groups for state restructuring is a flawed ideology that may sow the seeds for future conflicts in Nepal. There may be danger of ethnic cleansing (as in Bosnia, Rwanda or in the case of Jews during Nazi Germany) in which a process starts to define people only by their ethnicity or religion whether they are from very wealthy ethnic group or a poor, whether someone is a wealthy Brahmin /Chhetri or poor Hindu. The context of Indian federation (which is regarded very successful) is different. In India the bases of federation are characterized by geographic, regional, cultures and linguistic diversities. The vital feature of federalism is the division of powers between Central and State government and the autonomy enjoyed. The best democratic federalism, one could anticipate in Nepal need to be based on geographic, regional and economic factors with an acceptance of regional, cultural and linguistic differences in different parts of Nepal and proper democratic representation according to population. For this, the reconsideration of the electoral constituencies is indispensable so that to represent the populations in them that would gratify the concerns of the ethnic groups and their actual population is represented appropriately on the basis of universal rights rather than caste or ethnic identity. People of all religions, regions and caste hierarchies, including high caste Hindus in different regions, have been struggling to survive under miserable condition. There is no national ethnic policy in Nepal in the present nor there was in the past but the major issues can be whether Nepal can be a haven of all castes and ethnic groups residing in all regions in a real sense and whether the monopoly (in all sectors) of the few elites from dominant caste groups terminates. In this context, social policy should be to accomplish social integration which is a condition of achieving a relatively cohesive and functioning interaction system in a society among different people as a prerequisite to national integration. National integration is a progressive process of identifying commonalities with respect to common goods but it is imperative to uphold and endorse the distinct ethnic identity of each group through social integration within the framework of the current international political boundaries. Bhattachan and Pyakuryal rightly argue that to achieve national integration, all ethnic groups must have shared values in which the cultural aspirations of each groups are also reflected (17-38). But, the practice and implementation is difficult and different than discoursing. Achieving shared values and reflections of cultural aspirations of all groups is immensely difficult in a multicultural and multiethnic country. But we need to be optimistic for the possibilities for a better future as transformations and attitude changes are taking place gradually. The past 


\section{ETHNICITY, STEREOTYPES \& ETHNIC MOVEMENTS}

thinking of regarding ethic issue as communal is becoming flexible and the context for discoursing on ethnic issues and rights of ethnic groups is altering fluidly. However, inclusion of ethnic identity of each group through social integration within the framework of the current international political boundaries requires that ethnic and other marginalized groups need to develop the feeling of leadership, a self-confidence of leading all caste and ethnic groups. Excluded groups need to change stereotype thinking that they are excluded systematically, the entry point is tight, rather need to develop a competitive feeling by enhancing their aptitude in all sectors (including education). The dominant groups also need to change stereotype thinking on ethnic, caste, regional and federalism issues.

\section{CONCLUSION}

Ethnicity, in any society of the world, is fundamentally a procedure of categorization of people into different types in terms of various indications. This process of categorization and the consequent categories create social boundaries among people which are manifested in particular behavioral patterns in everyday life. As ethnicity does not always shoot out from antique tradition or nationality, however is fashioned, socially/culturally constructed, adapted, recreated, or even manufactured in the modern society, hence it is necessary to see ethnicity as process i.e. making of boundaries, fluidity of boundaries as well as the stiffening of boundaries, variations in categorization and identification among groups in different times and places. Therefore, State reorganization on the basis of capricious ethnic and religious history and so on will lead to confusion, disintegration and mayhem. Within the outline of the discussion made in the article, a prospective outlook in Nepal could be to focus on how the people categorize themselves and others as a particular ethnic/caste categories in terms of the markers they feel relevant, comprehend the ways social boundaries are created and maintained in everyday life of people in terms of attitudinal and behavioral aspects of prejudice as a result of ethnicity and caste based discrimination as a process of social categorization i.e. folk categorization and everyday life in historical context. For scholars and policy makers, the relationship between ethnic politics and democracy presents a dilemma. Ethnic politics repeatedly emerge in new democracies, and yet are often presumed to threaten new democracies. As ethnic politics is becoming increasingly central to Nepali politics, I argue it has the potential to strengthen rather than destabilize democracy if handled properly and addressed legitimately. How ethnic and caste parties operate on the ground, arguing that ethnic parties overlap considerably with social and political movements, and that the boundary between political parties and movements should be reconceptualised. Ethnic parties are not antithetical to democracy and that inclusion and democratization can proceed in diverse and unexpected ways. People's interpretations and rejoinder to inclusive democratization trends are often plural and depend on an assortment of cultural, societal, historical and even geopolitical factors as exemplified by the diverse democratic transitions experienced by Third Wave Asian countries since the 1980's and the Arab Spring of 2011. The process of inclusion and the vital role of education, democratization and federalism make new spaces for debate; stress on responsibility, credibility the questioning of state authority and the challenge of societal hierarchy and dominance patterns. In Nepal, the emergence of a democratic environment between the end of the dictatorial Panchayati era and the downfall of Hindu monarchy and establishment of Republic (for the first time in its history) in 2008, and the period of eighteen years (1990-2008) allowed new socio-political-economic and liberal constructions to take shape and the emergence of new debates on new forms of inclusive federal governance as envisioned by non-dominant ethnic and caste communities. 


\section{Crossing the Border: International Journal of Interdisciplinary Studies}

\section{WORKS CITED}

Barth, Fredrick. Introduction to Ethnic Groups and Boundaries. Ed. Fredrick Barth. Boston: Little Brown, 1969.

Beall, Jo and Piron, Laure-Hélène. Social Exclusion Review. London School of Economics Overseas Development Institute, 2005.

Bhattachan, Krishna B. 'Discourse on Social Exclusion and Inclusion in Nepal: Old wine in a New Bottle.' Identity and Society Social Exclusion and Inclusion in Nepal. Kathmandu: Mandala Book Point and Social Inclusion Research Fund (SIRF), 2009. 11.

Bhattachan, Krishna.B. and K. N. Pyakuryal. "The Issue of National Integration in Nepal: An Ethno-regional Approach." Occasional Paper in Sociology and Anthropology 5 (1996): 17-38.

Duffy, K. Social Exclusion and Human Dignity in Europe. Council of Europe, 1995.

Eriksen, T. H. Small Places Large Issues: An Introduction to Social and Cultural Anthropology. London: Pluto Press, 1995.

Gaize, Fredrick. Regionalism and National Unity in Nepal. Berkeley: University of California Press, 1975.

Gellner, D N, J. Pfaff-Czarnecka and J. Whelpton, eds. Nationalism and Ethnicity in a Hindu Kingdom: The Politics of Culture in Contemporary Nepal. Amsterdam, Harwood Publishers, 1997.

Gellner, D. N. "Nepal: Towards a Democratic Republic: Caste, Ethnicity and Equality in Nepal". Economic and Political Weekly of India 19.5 (May 2007): 18-25.

Guneratne, Arjun. Many Tongues, One People: The Making of Tharu Identity in Nepal. Ithaca: Cornell University Press, 2002.

Pfarr-Czarnecka, J., D. R. Senanayake, A. Nandy and E. T. Gomez. The State and Identity Politics in Asia. New Delhi: Sage Publications, 1999.

Popeau, J. "Race/Ethnicity." Core Sociological Dichotomies. Ed. C. Jenks. London: Sage Publication, 1998.

Regmi, Rishikeshav. "Ethnicity and Identity." Occasional Paper in Sociology and Anthropology 8 (2003): 1-11.

Room, Graham. Beyond the Threshold. The Measurement and Analysis of Social Exclusion. Bristol: Polity Press, 1995.

Scott, John and Gordon Marshall. Oxford Dictionary of Sociology. Oxford: Oxford University Press, 2009.

Sen, Amartya. Justice: Means versus Freedoms. Philosophy and Public Affairs, 1990.

Seymour-Smith, C., ed. Macmillan Dictionary of Anthropology. London: Macmillan, 1986.

Tylor, E. B. Dictionary of Anthropology. Delhi: W.R. Goyal Publisher and Distributors, 1999.

Whelpton, J. A History of Nepal. Cambridge: Cambridge University Press, , 2005. 